Anna Szafarczyk

\title{
THE REVIEW OF OBSERVER-CONTROLLED FACTORS ENSURING THE QUALITY OF RADAROMETRIC IMAGES TAKEN IN GBInSAR TECHNOLOGY AND THE METHODS OF THEIR VERIFICATION
}

\author{
AGH University of Science and Technology \\ szafarcz@agh.edu.pl
}

Keywords: ground based radar interferometry, quality of radarometric images, observer-controlled factors

\begin{abstract}
In the Ground Based InSAR technology, the proper setting the measurement conditions is a fundamental factor. The observer decides on the localization of radar both in horizontal and vertical plane, as well as the vertical angle of the antenna beam' inclination and on the form of the measurement stand, which has to be constructed or adapted. Depending on the observer's accuracy and optimization of the measurement procedures, the results can be loaded with bigger or smaller errors. The article presents observer-dependent factors, their influence on the accuracy of measurement with the accuracy analysis and author's geometric corrections of the obtained displacement values. The influence of the localization of radar on the resolution of the obtained radarogram was also discussed. The influence of the applied antennas and the distance to the target on the accuracy measurement were analyzed. The potential area that could be measured from one radar stand was defined. Due to the fact that the displacement values obtained in the direction of wave emission, the formulas were presented to allow the reduction of the obtained values to the values of horizontal displacements, introduced based on all the possible radar configurations in the relation to the monitored area. To obtain coherent images it is necessary to provide a stable radar stand. To achieve this, the measurement and calculation procedure of such control was presented. Following the recommendations formed in the conclusions presented in the article will allow obtaining the result of the highest possible accuracy.
\end{abstract}

\section{PRZEGLĄD KONTROLOWANYCH PRZEZ OBSERWATORA CZYNNIKÓW, KTÓRE WARUNKUJĄ JAKOŚĆ ZOBRAZOWAŃ RADAROMETRYCZNYCH WYKONANYCH W TECHNOLOGII GBInSAR WRAZ Z METODAMI ICH WERYFIKACJI}

Słowa kluczowe: naziemna interferometria radarowa, jakość zobrazowań radarometrycznych, czynniki zależne od obserwatora

\begin{abstract}
Abstrakt
W naziemnej technologii InSAR prawidłowe ustalenie warunków pomiaru jest czynnikiem fundamentalnym. Obserwator decyduje o lokalizacji radaru zarówno w płaszczyźnie poziomej, jak i pionowej, a także pionowym kącie pochylenia wiązki emitowanej przez radar oraz formie stanowiska pomiarowego, które należy samodzielnie wykonać lub zaadaptować. W zależności od prawidłowości i optymalizacji procedur pomiarowych podjętych przez obserwatora wyniki pomiaru mogą być obarczone większymi lub mniejszymi błędami. W artykule przedstawiono czynniki zależne od obserwatora, ich wpływ na dokładność pomiaru wraz z jego analizą dokładności oraz opracowanymi przez autora poprawkami geometrycznymi wartości przemieszczeń. Omówiono także wpływ wyboru pozycji (dystansu) radaru na rozdzielczość uzyskiwanego radarogramu. Przeanalizo-
\end{abstract}


wano wpływ zastosowanych anten oraz długości celowej na dokładność pomiaru oraz określono potencjalne pole powierzchni możliwe do pomiaru z jednego stanowiska radaru. Ze względu na fakt uzyskiwania wartości przemieszczeń na kierunku emisji fali, przedstawiono wzory pozwalające na zredukowanie uzyskanych wartości do wartości przemieszczeń poziomych, które wyprowadzono w oparciu o wszystkie możliwe konfiguracje radaru względem monitorowanej powierzchni. W celu uzyskiwania koherentnych obrazów konieczne jest zapewnienie stabilnego stanowiska. W tym celu przedstawiono procedurę pomiarową i obliczeniową takiej kontroli. Zastosowanie się do wniosków przedstawionych w artykule pozwoli na uzyskanie zobrazowania radarometrycznego o najwyższej możliwej dokładności.

\section{INTRODUCTION}

One of possible technologies of the displacement measurement in the natural slopes and scarps of the open pit mines is ground based radar interferometry (Monserrat O. et al. 2014, Gocał J. et al. 2013). This method is based on the same principles as satellite radar interferometry called InSAR (Simons, M., Rosen, P., 2007, Grzybek, R. 2017, Witkowski W. et al. 2017), with such difference that the radar is installed on the ground surface. The choice of the radar's location towards the measured area has a significant influence on the quality, accuracy and the interpretation of the obtained measurements (radarograms). Author's own experience in the landslide monitoring (Szafarczyk A. et al., 2013) indicate that the conditions of the measurement are usually other than optimal, which diminishes the quality of the obtained images. The literature (Krawczyk, A., Perski, Z. 2000) presents factors influencing the quality of interferometric satellite image the control of which and minimization of errors before taking the image are practically impossible. There are, however many factors controlled by the observer, influencing the quality of radarometric images, the interpretation, analysis and verification of which are very important.

\section{GROUND BASED InSAR TECHNOLOGY}

Compared to other remote technologies carried out from ground, ground based radar interferometry has the possibility of the measurement from large distance, short time of obtaining information as well as the form (vectors in space) and accuracy of the determined values dislocations (Monserrat, 2014). The measurements with the application of ground-based radar interferometry were carried out with IBIS-L radar. The basic characteristics of this radar were presented in table 1 .

Table 1. Characteristics of ground based radar interferometry, focus on radar IBiS-L (IBIS-L..., 2008)

Tab. 1. Charakterystyka naziemnej interferometrii radarowej na przykładzie radaru IBiS-L (IBIS-L..., 2008).

\begin{tabular}{|l|l|}
\hline Feature/Parameter & Characteristics/Value \\
\hline Observable distance & up to $4 \mathrm{~km}$ (maximum) \\
\hline Range resolution & $\Delta \mathrm{R}=0.75 \mathrm{~m}$ \\
\hline Cross-range resolution & $\Delta \mathrm{CR}=4.5 \mathrm{mrad} \mathrm{x}$ distance \\
\hline Time necessary to get information & 12 minutes (2.5 minutes minimum) \\
\hline Typical time of data acquisition & About 2.5 minutes for the full-resolution image in 2-km distance \\
\hline Frequency of the measurement & Continuous or inter acquisition delay declared by the user \\
\hline Accuracy & Maximal possible 0.01 mm \\
\hline Influence of atmospheric conditions & Reduction of atmospheric effects \\
\hline The way of the installation & Permanent (fixed) or mobile \\
\hline Module structure & $\begin{array}{l}\text { Basic elements: radar, linear scanner, power supply module } \\
\text { Additional elements: photovoltaic power, Wi-Fi, high-resolution camera, weather } \\
\text { station }\end{array}$ \\
\hline
\end{tabular}


The instrument consisting of several modules is set for the time of making measurement opposite to the measured slope in the way guaranteeing its stability and good vision on the whole monitored area (Szafarczyk, 2016a). In case of open cast mines, the best radar position is putting it as high as possible on a scarp opposite the monitored area, at the height guaranteeing the visibility of the surface of the roads and ramps. If it is impossible to fix the stand in a stable way on the scarp, it is also acceptable to situate the radar on the pit floor, however one should take into account the occurrence of „blind spots” in the obtained radar image. An important factor influencing the choice of the stand can be also the access to power supply.

\section{RESOLUTION}

The resolution of the radar image made in the technology of ground based radar interferometry is described by two values: range resolution $(\Delta \mathrm{R})$ and crossrange resolution $(\triangle \mathrm{CR})$ (IBIS-L..., 2008).

Range resolution in the direction of the wave emission is constant for a definite wavelength. It depends on the frequency of the signal used by the radar (in case of IBIS radar it is $0.5 \mathrm{~m}$ ). The cross-range resolution, on the other hand, depends on the distance to the object (the pixel size increases in the plane perpendicular to the emitted signal, causing linear growth of the pixel area). For example, the size of the pixel of the radar image of the area in the distance of $100 \mathrm{~m}$ from the radar would correspond the area of $0.2 \mathrm{~m}^{2}$ and a pixel for maximal distance of $4 \mathrm{~km}$ would be equivalent to the area of $9 \mathrm{~m}^{2}$.
High resolution of the obtained radar images makes it possible to detect changes on very small areas corresponding several pixels of the image i.e. the area from less than ten to several dozen square meters.

\section{THE RANGE AND ACCURACY OF THE MEASUREMENT}

In the technology of ground based radar interferometry, the radar is installed on a selected stand in the way that clearly defines the possibility of making the measurement in the plane of the horizon. This means that it is not possible to measure in any direction getting out from the measurement stand, like in the case of classical surveying equipment. Some section of the space covered with the range of the operation of radar is defined by two angles called half power beamwidth angles, defined for the vertical and horizontal planes (Bem, 1973). These angles are across the main lobe of an antenna pattern between the two directions at which the antenna's sensitivity is half its maximum value at the center of the lobe. The smaller the half power beamwidth angle is, the more the antenna's power is focused on the direction of the main radiation, and this way their directivity increases. For example, narrow-angle aerial is characterized by a small range in a horizontal plane having 11 angular degrees and nearly 10 angular degrees in a vertical plane (Fig. 2). The area covered by the measurement with the application of aerials of this kind in the maximal distance of 4 kilometers would be above $500000 \mathrm{~m}^{2}$. To compare with the broad-angle aerial is characterized by the range in horizontal plane covering

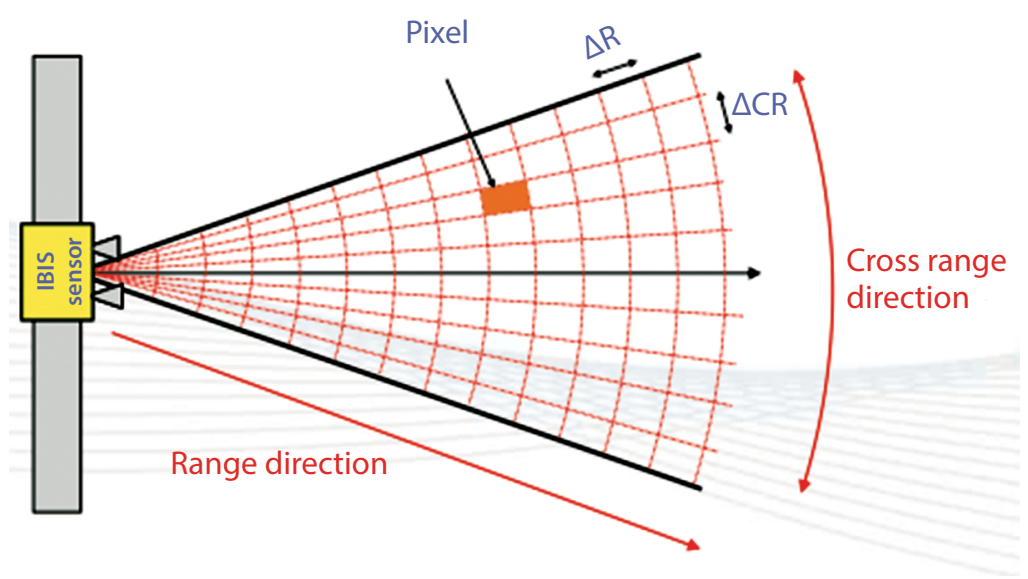

Fig. 1. Range resolution and cross-range resolution (IBIS-L..., 2008)

Rys. 1. Rozdzielczość odległościowa i rozdzielczość kątowa (IBIS-L..., 2008) 


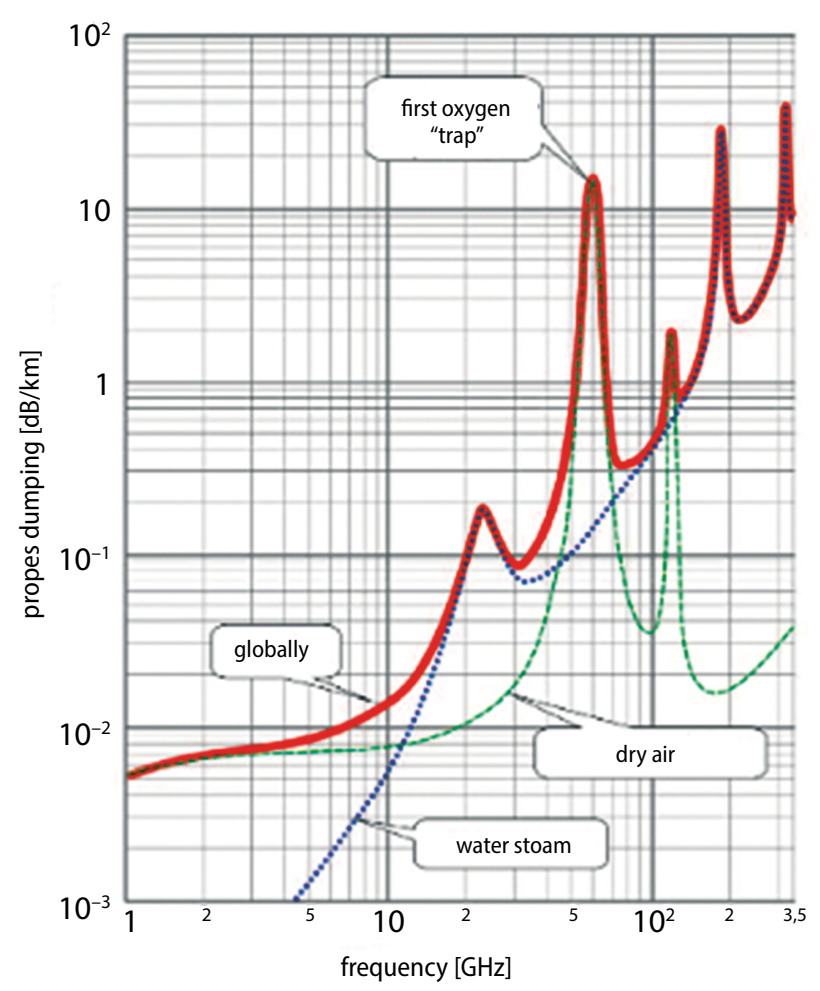

Fig. 2. Specific attenuation due to atmospheric gases for an electromagnetic wave in the function of frequency. (ITU-R Recommendations..., 2001)

Rys. 2. Tłumienie właściwe powietrza dla fali elektromagnetycznej w funkcji częstotliwości. (ITU-R Recommendations..., 2001)
38 degrees and 18 degrees in the vertical plane, respectively, which causes that it can be applied in marking the deformations of the scarp of the area above 3 million $\mathrm{m}^{2}$ on a maximal distance of 4 kilometers (Table 2).

The value integrally connected with the range of the carried out measurement is value called signal to noise ratio, which compares the level of the power of the signal emitted by the antenna to the level of noise and is usually expressed in decibels $(\mathrm{dB})$ for each pixel (Surhone, L.M. et al., 2010). Higher value means better specification and higher accuracy of the measurement. E.g, when the ratio of signal to noise is $100 \mathrm{~dB}$, this means that the level of the signal is $100 \mathrm{~dB}$ higher than the level of noise.

The propagation of the waves emitted by the radar first of all depends on their length, polarization and environmental conditions. This is connected with electric parameters of the surroundings, but also with the relief and land cover (water, forest, open area). The conditions of the propagation of waves are not only different for different wave range, but also are subdued to periodical changes: daily, annual, as well as in longer periods, connected e.g. with 11 years' cycles of solar activity (ITU-R Recommendations..., 2001).

The damping of electromagnetic waves in space depends on many factors, first of all the distance and frequency. In the earth atmosphere the waves are addi-

Tab. 2. The relationship between the surveyed area and the distance of the instrument from this area and the applied antennas Tab. 2. Zależność pola powierzchni objętej pomiarem od odległości instrumentu od tej powierzchni i zastosowanych anten

\begin{tabular}{|l|l|l|}
\hline $\begin{array}{c}\text { Distance between } \\
\text { the examined area } \\
\text { and the radar }\end{array}$ & \multicolumn{1}{|c|}{$\begin{array}{c}\text { Area covered by the range } \\
\text { of the narrow-angle antennas }\end{array}$} \\
\hline & $\begin{array}{l}\text { Area covered by the range } \\
\text { of the broad-angle antennas }\end{array}$ \\
\hline $1 \mathrm{~km}$ & 1.6 hectare & 20 hectares \\
\hline $2 \mathrm{~km}$ & 14 hectares & 80 hectares \\
\hline $3 \mathrm{~km}$ & 30 hectares & 321 hectares \\
\hline $4 \mathrm{~km}$ & 53 hectares & 321 hectares \\
\hline
\end{tabular}


tionally damped due to the absorption of energy by the particles of gases in the air. Although this absorption is insignificant in the area of small frequencies, in the area of microwave frequencies it is a very significant phenomenon. Generally speaking, the absorption of energy grows with the growth of frequency, while for some frequencies a rapid growth of damping is observed, which is caused by the impact of electromagnetic waves into molecules of individual types of gases contained in the atmosphere. Fig 2 presents the dependence of so-called specific attenuation coefficient on frequency. The coefficient is connected with gases contained in the earth atmosphere (ITU-R Recommendations..., 2001).

The accuracy of the measurement of dislocations marked with the application of the technology of ground based radar interferometry is defined by the producer and equals $0.1 \mathrm{~mm}$ (IBIS-L..., 2008). It refers to the measurement of dislocations in the direction of wave emission called line of sight (LOS), for the points of „good reflexibility” of the defined value SNR $>50 \mathrm{~dB}$

In the measurement practice, the pixels of the image made for the surface of the slope of the quarry is not characterized by the SNR value exceeding $50 \mathrm{~dB}$ and because of this, the accuracy of the measurement is significantly smaller (one order of magnitude down) than the value declared by the producer.

In the applied cases of the measurement (Szafarczyk, A. et al. 2013), the average value of SNR, for pixels representing the area of scarps equals $11-20 \mathrm{~dB}$, which makes the measurement accuracy deteriorate to $1 \mathrm{~mm}$, while for objects of very good reflectivity (above $40 \mathrm{~dB}$ ) equals $0.01 \mathrm{~mm}$ or less (Fig. 3).

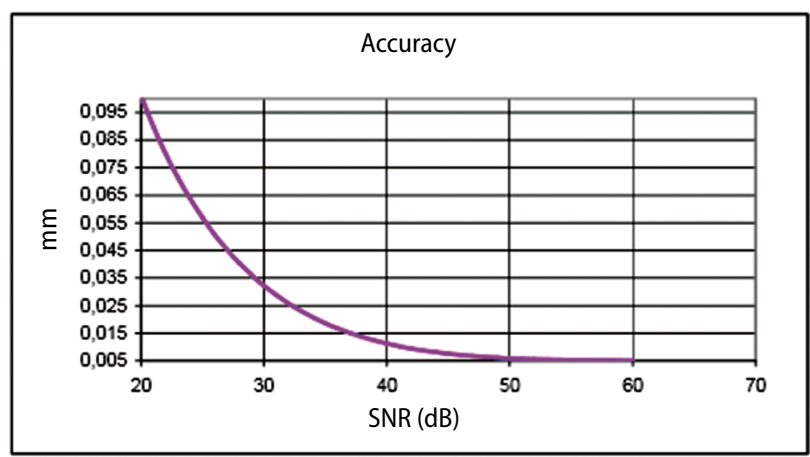

Fig. 3. Measurement accuracy in GBInSAR as a function of signal to noise ratio (IDS, 2008)

Rys. 3. Dokładność pomiaru w technologii GBInSAR jako funkcja wartości SNR (IDS, 2008)

\section{CORRECTION OF THE MEASUREMENT RESULTS}

In the technology of ground based radar interferometry the radar signal is an electromagnetic wave of frequency in band $\mathrm{Ku}$ (12-18 GHZ), the wave length is $17 \mathrm{~mm}$ (Ogundare, 2015). This wave is classified as ground wave, propagated in the air at the border airground. The atmospheric conditions, especially temperature and humidity influence the propagation of the wave.

To eliminate the influence of atmospheric conditions on the results of the measurement, the control points are indicated in the obtained image. They are called ground control points and are characterized by a great SNR value and do not change its situation during the measurement. These points have zero value of dislocation attributed, and the remaining dislocation values are automatically corrected (Szafarczyk, 2017). The effect of the carried out correction is obtaining real values of dislocations occurring in the direction of the emission of the radar wave in so-called line of sight and the described relation (IBIS-L..., 2008):

$$
d_{l o s}=-\frac{\lambda}{4 \pi} \Delta \varphi,
$$

where:

$\lambda-$ wave length,

$\Delta \varphi$ - difference between phases of signal returning after the reflection from the object in the first and second measurement.

To determine real values of dislocations, it is necessary to know mutual geometric relations taking place between the signal emitted by the radar and the area monitored, with its inclination, which, contrary to satellite radar interferometry depends on the observers and their decisions referring to the situation of the measurement stand, the direction of wave emission in the horizontal plane and vertical plane.

For the monitored vertical plane and the radar emitting waves in the vertical angle $\alpha$ over the horizon (fig. 5a), displacement in line of sight $d_{\text {los }}$ is reduced according to the relation:

$$
d=\cos \alpha * d_{l o s}
$$

When the waves emitted by radar are inclined in the same angle, but on the inclined surface, as presented in fig. $5 \mathrm{~b}$, the reduction is according to the formula: 


$$
d=\cos \alpha \cdot d_{\text {los }}-\frac{d_{l o s} \cdot \sin \alpha}{\tan \beta}
$$

This is a typical configuration of radar in the monitoring of landslides or slopes of the mine scarps. At such configuration, real horizontal displacements are smaller than observed ones.

In the situation, when the radar is situated higher than the monitored area and emits waves with the angle $\alpha$ in the relation to the horizontal plane (fig. 6a), the reduction of displacements obtained in the line of sight $\left(d_{l o s}\right)$, into real values of horizontal displacements in case of the vertical object, there is the following formula:

$$
d=\cos \alpha * d_{l o s},
$$

and in the case of the object inclined to the level with angle $\beta$ (fig. $6 \mathrm{~b}$ ) according to the formula:

$$
d=\cos \alpha \cdot d_{l o s}-\frac{d_{l o s} \cdot \sin \alpha}{\tan \beta} .
$$

In such a case real horizontal displacements are bigger than observed.
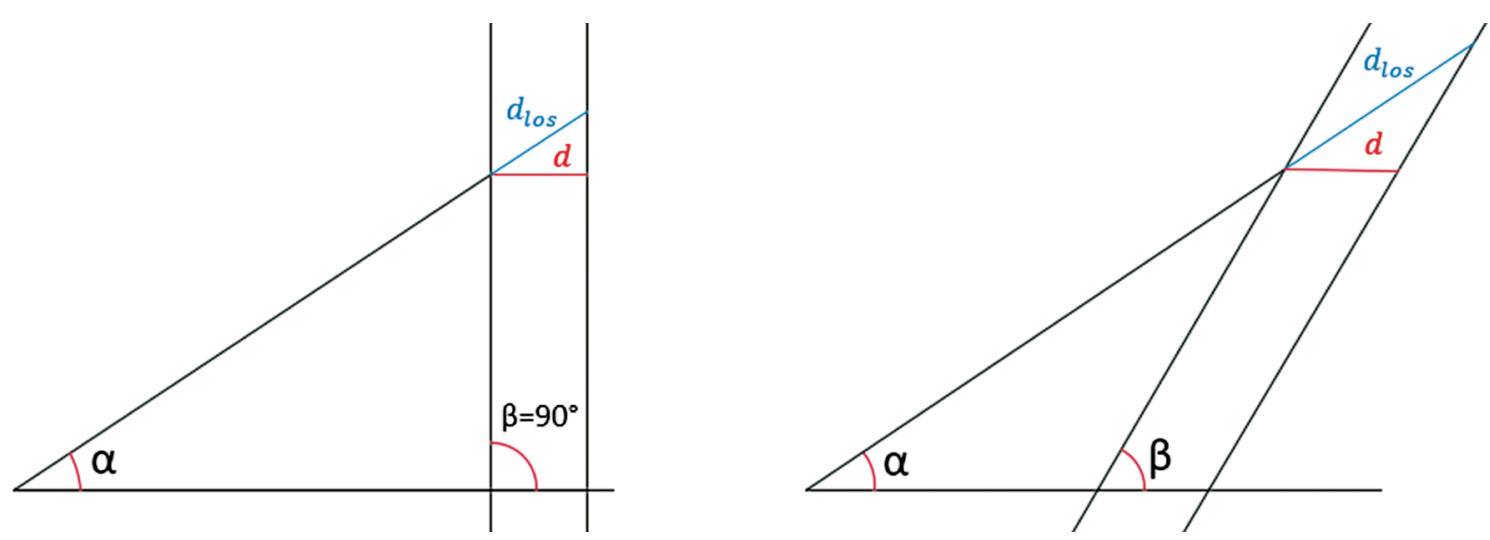

Fig. 5. Determining the values of horizontal dislocation at waves emitted by radar, with angle $\alpha$ over the plane of horizon a) for the monitored vertical object $b$ ) for the monitored object inclined with angle $\beta$ to the horizontal plane.

Rys. 5. Wyznaczenie wartości przemieszczenia poziomego przy falach emitowanych przez radar pod kątem $\alpha$ ponad płaszczyzną horyzontu, a) dla obiektu monitorowanego pionowego, b) dla obiektu monitorowanego nachylonego pod kątem $\beta$ do płaszczyzny poziomej
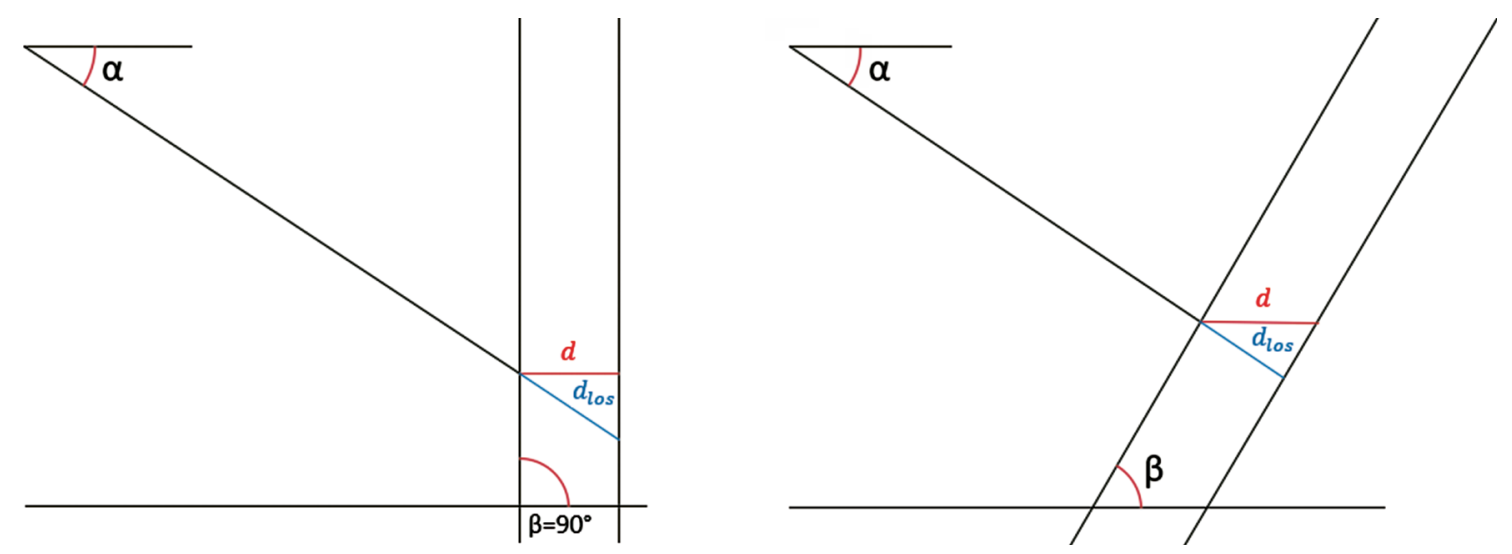

Fig. 6. Marking the values of horizontal displacements at waves emitted by the radar with angle $\alpha$ below the plane of horizon a) for the monitored vertical object $b$ ) for the monitored object inclined with the angle $\beta$ to the horizontal plane

Rys. 6. Wyznaczenie wartości przemieszczenia poziomego przy falach emitowanych przez radar pod kątem $\alpha$ poniżej płaszczyzny horyzontu, a) dla obiektu monitorowanego pionowego, b) dla obiektu monitorowanego nachylonego pod kątem $\beta$ do płaszczyzny poziomej 


\section{CONTROLLING THE STABILITY OF THE MEASUREMENT STAND}

One of the conditions to get correct results of the measurement carried out with the technology of ground based radar interferometry is the stability of the measurement stand. One should understand both stability of the ground on which the radar is carried out, as well as the stability to the same instrument and its situation. The radar, depending on the goal of the measurement (measurements of quickly changing movements or the movements occurring in a long time) it is situated on a tripod or on a concrete plinth. In case of determining dislocations revealed in a long time, the concrete plinth, making the base for linear scanner on which the radar moves has to be absolutely stable. The failure to fulfill this condition would generate errors in the obtained results in the displacements of the monitored area, and the value of these errors would depend on mutual geometric relations between the situation of the radar, and the monitored area, as well as on the direction and the value of the inclination of the fundament, which can result from uneven subsidence.

The radar is not placed on a typical geodetic tripod, does not have a tribrach, and during the measurement it moves on the aluminum linear scanner fixed on a stable concrete plinth below the freezing level. The measurement can be carried out in a continuous mode, for many days or in series, requiring putting the linear scanner and radar again on the plinth. In case of the serial measurement it is necessary to apply such a construction, which guarantees that the instrument is situated in the same way as before, with highest possible precision being the equivalent of forced centering. For this purpose, the concrete plinth is equipped with five threaded rods, on which the linear scanner is fixed. The liner scanner is an integral part of the measurement set (fig. 7).

Correctness of fixing the threads, and especially securing the unchangeable situation of plinth make the base for the consistent observations, and consequently the correctness in the interpretation of the measurement results.

The result of the measurement made with the ground based interferometric radar is a two-dimension image (radarogram). Every pixel of such an image, taking the shape of trapeze made of curves (Fig. 1), contains data on the phase and amplitude of returning signal. Determining the dislocations is possible after making at least two radarograms of a given stand (plinth). Overlapping two such images (diversification in phase) allows getting interferogram, on which every pixel contains information on displacement. The displacement value for each pixel is presented in the scale of colors put in the legend (Guido, 2010).

During making the interferogram, it is assumed that both radarograms are carried out with the instrument,

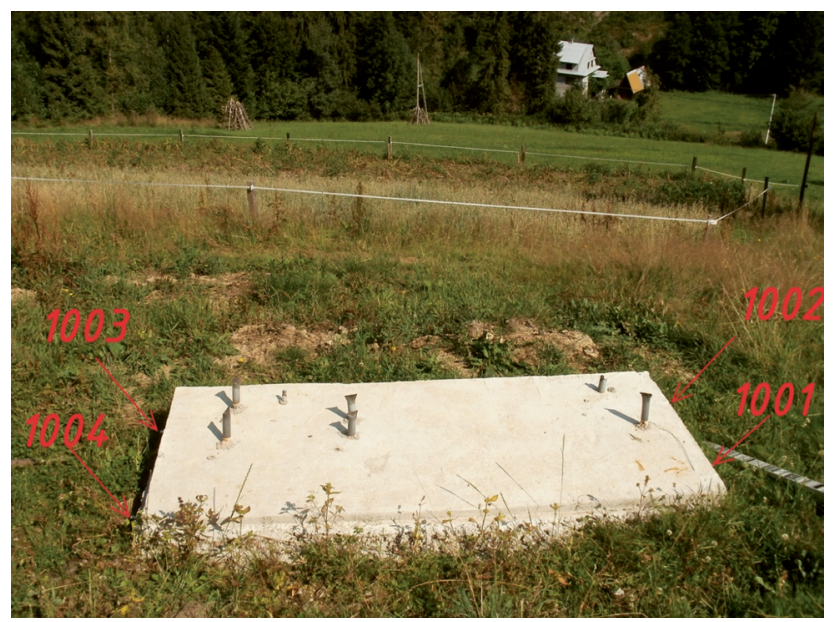

Fig. 7. The measurement stand a) the situation of radar on the aluminum linear scanner fixed on the threads put in a concrete plinth b) localization of benchmarks used in the assessment of the stability of the concrete fundament for the aluminum rail Rys. 7. Stanowisko pomiarowe, a) sposób ustawienia radaru na aluminiowej szynie montowanej na gwintach osadzonych w betonowym postumencie, b) lokalizacja reperów wykorzystywanych do oceny stabilności betonowego fundamentu 
which did not change its situation between the carried out measurement series. This assumption is necessary to obtain the consistence of radarograms and thus it guarantees generating a correct interferogram. To achieve this goal, for the carried out measurements one should the apply the procedure of checking the condition of a rigid body (Janusz, 2005).

A rigid body is a body where all the points are always in the same distance from one another. During the movement, the system of the material points making a rigid body moves as the whole, without changing the form and volume. The rigid body is not subdued to strains. To clearly define its situation in space, one should know the situation of at least three points. The situation of the rigid body is described by 3 co-ordinates and 3 angles. This object fulfils the condition of a rigid body, if the mean approximation error is smaller than the triple value mean square error of determining the dislocation (Janusz, 2005).

The mean approximation error is:

$$
\mathrm{m}_{\mathrm{a}}= \pm \sqrt{\frac{[\mathrm{vv}]}{\mathrm{n}-\mathrm{u}}}
$$

where:

$[\mathrm{vv}]$ - the sum of the squares of deviations,

$\mathrm{n}$ - the number of observations,

$\mathrm{u} \quad$ - the number of surplus observations.

Mean square error of determining dislocations is described by the relationship:

$$
\mathrm{m}_{\mathrm{u}}= \pm \sqrt{\frac{\left[\mathrm{m}_{\mathrm{u}_{\mathrm{i}}} \mathrm{m}_{\mathrm{u}_{\mathrm{i}}}\right]}{\mathrm{n}}},
$$

where:

$\mathrm{m}_{\mathrm{u} 1}$ - the displacement error in a given point,

$\mathrm{n}$ - the number of observations.

Condition of a rigid body is described as:

$$
\mathrm{m}_{\mathrm{a}} \leq 3 \mathrm{~m}_{\mathrm{u}}
$$

To make it possible to state that the rigid body condition was fulfilled, there should be more than 3 benchmarks $(n>3)$ installed on the object. Due to such assumption, one can also indicate the places where the fundament is weaker, e.g., because of the local washout of the ground (Janusz, 2005).

\section{THE RULES OF THE PROPER PLANNING AND VERIFICATION OF THE MEASUREMENT}

Taking into account the mentioned above factors depending on the observer, and influencing the quality of the carried out measurements with the use of graound based radar interferometry, one should take into account that the accuracy is declared by the producer will be fulfilled, as far as basic rules of proper planning and carrying out the measurement are fulfilled. The factors are shown in table 3.

Making measurements with the application of ground based radar interferometry technology should be preceded with the field survey, during which the visibility analysis on the studied object is done and the radar stand is chosen in the place guaranteeing its stability. Because the choice of the radar localization

Tab. 3. Factors depending on the observer and influencing the accuracy of dislocation measurements determined with the application of GBInSAR

\begin{tabular}{|c|c|}
\hline Factor influencing measurement results & The way of the correctness verification \\
\hline The size of the measurement pixel & The choice of the stand as close as possible to the object \\
\hline Optimization of the area covered with the measurement & $\begin{array}{l}\text { Application of proper antennas and proper situation } \\
\text { of the radar }\end{array}$ \\
\hline Removal of the influence of atmospheric effects & $\begin{array}{l}\text { Application of correction with the application of ground } \\
\text { control points }\end{array}$ \\
\hline Proper localization & The choice of localization that does not make blind spots \\
\hline Stability of the instrument & Checking the rigid body condition \\
\hline
\end{tabular}

Tab. 3. Zestawienie czynników zależnych od obserwatora, mających wpływ na dokładność przemieszczeń wyznaczanych z wykorzystaniem GBInSAR 
in a definite distance from the monitored object determines the resolution of the obtained image, theoretically it is the best to localize radar as close as possible to the object of the studies. However, with diminishing the distance between the radar and the studied object the area covered with the range of the radar antennas also diminishes. So the values put in table 2 are helpful in the localization of the radar.

\section{CONCLUSIONS}

In case of the monitoring of slopes and scarps of open pit mines, carried out to secure the safety of a mining enterprise, it is not absolutely necessary to install points of GCP type (Szafarczyk, A. 2016b), and it is sufficient to select the measurement pixel of high SNR value; and based on this, to make a correction for changeable atmospheric reflexivity and to provide the highest possible measurement accuracy, it is necessary to apply GCP points and it is done according to the rules presented in the publication (Szafarczyk, 2016).

To obtain coherent radarograms, the necessary condition is carrying out the obsevations from a stable stand, which should be controlled according to the rules presented in section 6 .

After carrying out the measurements, to provide maximal possible precision to determine the real displacement values the geometric correction in made, according to the relations presented in chapter 5 . As a result of setting radar above the monitored scarp, values lower than real displacement values are obtained, and in the situation of placing the radar below the monitored scarp, the values are higher than the real displacement values.

This discussion can be useful for open pit mines, because, according to the Enactment (Rozporzadzenie..., 2013), the geological and surveying staff of the mine make geodetic documentation of the landslide phenomena occurring in the area of mining excavations and in the region of the overburden storages. This documentation is made based on the results of geodetic measurements, which, due to the existing threat, it is the safest to apply remote measurement technologies.

\section{ACKNOWLEDGEMENT}

The publication is financed by the funds of the Department of Mine Areas Protection, Geoinformatics and Mine Surveying no. 18.18.150.195

\section{LITERATURE}

Bem, D.J. (1973) Anteny i rozchodzenie się fal radiowych. WNT, p. 327-336

Dehls, J.F. et al. (2014) Use of Satellite and Ground Based InSAR in Hazard Classification of Unstable Rock Slopes. In: Sassa K., Canuti P., Yin Y. (eds) Landslide Science for a Safer Geoenvironment. Springer, Cham, p. 389-392 DOI https:// doi.org/10.1007/978-3-319-05050-8_60

Gocał, J. et al. (2013) Determination of displacement and vibrations of engineering structures using ground-based radar interferometry. AGH University of Science and Technology Press, Kraków, 264 pages

Grzybek, R. (2017) Identification and analysis of mining areas subsidence with using InSAR technique based on sentinel-1 SAR imagery. Geoinformatica Polonica, Vol.16 (2017), p. 53-67, online publication date: 14.09 .2017

Guido, L. (2010). Ground Based SAR Interferometry: a Novel Tool for Geoscience, Geoscience and Remote Sensing New Achievements, Pasquale Imperatore and Daniele Riccio (Ed.), ISBN: 978-953-7619-97-8, InTech, Available from: http://www.intechopen.com/books/geoscience-and-remote-sensing-newachievements/ground-based-sar-interferometry-a-novel-tool-for-geoscience

IBIS-L Controller ver.02.00.000 - User Manual, IDS, (2008)

ITU-R Recommendations, Attenuation by atmospheric gases, ITU-R P.676-5, Geneva, (2001)

Janusz, W. (2005) Metoda obliczania pionowych przemieszczeń i deformacji fundamentu budowli z identyfikacją i uwzględnieniem symptomów jego nieciągłości. Prace Instytutu Geodezji i Kartografii, tom LI, zeszyt 109

Krawczyk, A., Perski, Z. (2000) - Application of satellite radar interferometry on the areas of underground exploitation of copper ore in LGOM-Poland. International Congress of the International Society for Mine Surveying, 2: 209-218

Monserrat, O., Crosetto, M., Luzi, G. (2014) A review of groundbased SAR interferometry for deformation measurement. ISPRS Journal of Photogrammetry and Remote Sensing, Volume 93, p. 40-48.

Ogundare, J.O., (2015) Precision Surveying: The Principles and Geomatics Practice, John Wiley and Sons, Inc., Hoboken, New Jersey, 620 pages

Rozporządzenie Ministra Gospodarki z dnia 8.04.2013 r. w sprawie szczegółowych wymagań dotyczących prowadzenia ruchu odkrywkowego zakładu górniczego, Dziennik Ustaw, 2013, poz. 1008

Simons, M., Rosen, P., (2007) Interferometric Synthetic Aperture Radar Geodesy Treatise on Geophysics, Schubert, G. (ed.), Volume 3- Geodesy, Elsevier Press, p. 391-446, http://www. gps.caltech.edu/ simons/pdfs/Simons_Treatise.pdf

Surhone, L.M., Timpledon, M.T., Marseken, S.F. (2010) Signal to Noise Ratio (Image processing), VDM Publishing, 128 pages

Szafarczyk, A., Rybicki, S., Woźniak, H., Lenda, G., Kaczmarczyk, R., Ligas, M., Krokoszyński P., Gawałkiewicz, R., Tchórzewska, S., Szymanowski, R. (2013) Badania kine- 
matyki powierzchniowych ruchów masowych z wykorzystaniem naziemnej interferometrii radarowej, Szafarczyk, A. and Rybicki, S. (ed), Wydawnictwa AGH, Kraków, pp. 126

Szafarczyk, A. (2016a) Application of modern measurement technologies in the displacement determination, ESASGD International conferences on Earth sciences and sustainable geo-resources development, Vietnam, p. 282-291
Szafarczyk, A. (2016b) Using corner reflectors as ground control points in ground based SAR interferometry. International Multidisciplinary Scientific GeoConference SGEM 2017 Vol. 17 iss. 22, Geodesy and mine surveying. Sofia p. 749-756

Witkowski, W., Malinowska, A., Hejmanowski, R. (2017) Evaluation of the Sentinel-1A radar interferometry accuracy applied in mining areas. Przegląd Górniczy, vol. 73 no 1, p. 78-83 